\title{
Om Billedsproget i Grundtvigs sidste digt
}

\section{Af William Michelsen}

Vartovbogen 1993, redigeret af Anna Bojsen-Mфller, Jørgen Kristensen og E. Jakob Petersen. Kirkeligt Samfunds Forlag, Kфbenhavn 1993.90 kr.

Udvendigt set er denne Vartovbog ikke forskellig fra de foregående. Bogen ender og begynder med betragtninger over den nye bibeloversættelse og kirkens gudstjenester. Men mellem disse finder man f.eks. en artikel om »Rushdie, fundamentalisme og politik «, og dén handler ikke om Islam og kristendommen, men om baggrunden for den konkrete politiske situation, skrevet af universitetslektor Lars Erslev Andersen fra Odense, og et referat af Georg Brandes' essay fra 1890: »Det store Menneske, Kulturens Kilde« med nutidig kommentar af Sidsel Wåhlin, Brabrand. Vartovbogens udgangspunkt er stadig »Grundtvigs kirkelige og folkelige tanker«, som det hedder på bagsiden af titelbladet, men dem mærker man ikke meget til. Heller ikke i cand. theol. Kirsten Sarauws foredrag i serien »Guds billeder « fra Teologisk Forening i Aarhus. Foredraget har overskriften: »Gud er død - Gud leve!«. Langt mere i sognepræst Jakob Ørtveds afsluttende artikel, der begynder og ender med et forsvar for Grundtvigs julevers: »På stjernetæpper lyseblå skal glade vi til kirke gå«.

En af mine døtre spurgte mig forleden: »Hvorfra stammer de ord: »... med venner i lys vi tale«? $\ll$ Hun ville forklare dem for sine arabiske elever på indvandrerskolen i Ballerup. Dér har vi kultursammenstødet $\mathrm{i}$ et land og en generation, som har glemt sin egen kultur, men er ved at genopdage den. Som det ses i Pia Skogemans artikel om kirken i lokalsamfundet - i Ishøj, den folkerigeste kommune i Danmark, hvis indbyggertal er tidoblet i løbet af 20-30 år, en forstad til København med 14\% indvandrere. Situationen afspejles måske skarpest $\mathrm{i}$ en række billeder af Tine Hind, som er bogens kunstner.

I denne anmeldelse er der imidlertid mest grund til at omtale Bent Noacks artikel om Grundtvigs sidste digt, hvis tekst også er emnet for en artikel af Flemming Lundgreen-Nielsen her i Grundtvig-Studier. Problemet for Noack som for Lundgreen-Nielsen er ordet »Sjæle-Færge-Stavnen« i næstsidste linie af 3 . strofe. Han accepterer det, men skriver alligevel om digteren: »Eller skrev han »sjæleøje-stavnen«?« som den første udgiver, Sven Grundtvig læste, og som også står i teksten til Thomas Laubs kongeniale melodi til digtet.

Det er nok det ejendommeligste af Grundtvigs mange digte om døden, og Noack gennemgår dets udtryk med stor viden og indlevelse. Hans artikel 
kan tåle at læses flere gange. Han har også gennemgået digtet $\mathrm{i}$ et foredrag for Grundtvig-Selskabet ved et årsmøde i Århus.

Digteren Grundtvig havde både en symbolverden og et billedsprog, som var produktive, så længe han levede. Hans symbolverden var præget af den nordiske mytologi og de danske folkeviser og folkesagn, især med emner fra de danske kongers historie. (At han aldrig skrev nogen Danmarkshistorie, har han begrundet med, at han ikke vidste, hvad han i den skulle gøre ved de danske sagn.) Det var afgørende for hans kristne digtning, at han gennem det angelsaksiske digt om Beowulf konstaterede, at der fandtes en kristen digtning med en f $\phi$-kristen symbolverden, og at han senere i England ligefrem fandt digte, der udtrykte det kristne evangelium i et billedsprog, hentet fra den før-kristne mytologi. Det gav ham mod til at bruge den nordiske mytologis symbolverden i sin personlige kristne digtning og i sine salmer. Det er, hvad han gør i det sidste digt, vi kender fra hans hånd.

Noacks artikel optrykker digtet med moderne retskrivning. Han fremhæver, at det ikke er nogen salme, og at Thomas Laubs melodi kun kan synges som solosang. Det blev - måske første gang - sunget ved en mindefest for Joakim Skovgaard i Københavns rådhus (af Albert Høeberg), og Noack nævner, at det blev sunget ved Hal Kochs begravelse. Melodien står i »Thomas Laub: Tolv Viser og Sange af danske Digtere « udg. af Konrad Jørgensens bogtrykkeri, Kolding, 1932, dvs. efter komponistens død.

Kommentaren til digtet i 6. bind af Grundtvigs Sang-Værk, 1964, skriver: »Sjæle-Færge-Stavnen hentyder til den græske Myte om Karon, der i en Baad fører de afdødes Sjæle til Hades.« Men Grundtvig plejer ikke at sammenblande græsk og nordisk mytologi på en så vilkårlig måde, og dette digt er i sit billedsprog og sin symbolverden i god overensstemmelse med hans $\emptyset$ vrige digtning.

Selv om digtet ikke er nogen salme, er det alligevel et digt, der vedkommer os andre, kristne og ikke-kristne. Det indledes ganske vist som et rent personligt digt. Men det fortolker hans situation i hans 89 . år i et billedsprog, der er almenmenneskeligt: »Nærmest er de Dødes Rige, Nemt det er at stævne did. Men o vee for Uglesangen Bundløs der er Undergangen.« Den nordiske mytologi har ingen myte om en færgemand, der i en båd fører de afdødes sjæle til dødsriget, og det er ingen sådan, der skildres i dette digt. Det er ikke en sådan båd over en flod, Grundtvig forestiller sig i 1. strofe, hvor han »staaer paa Falderebet« til et skib, »Ved det store, vilde Hav«, hvor »Aanden staaer for Styret«, dvs er styrmand, ja, det hedder endog i 1 . strofe, at »Guds Aand staaer selv ved Roret «, og at »Magneten er Guds-Ordet «.

Det ejendommelige ved digtet er, som fremhævet af Noack, at Grundtvig her forestiller sig døden som »det store, vilde Hav«, hvor »Stormene er frygtelige, Stille staaer her Mandevid«. Hvordan kan man på et sådant hav 
tale om en »færgestavn«? - Ja, i vore dage er det jo så nemt at komme med en jernbanefærge fra Sjælland til Fyn eller med en bilfærge til Jylland, så længe man ikke har bygget en bro over vore bælter og sunde. Men sådan var det ikke i Grundtvigs levetid. Og dog forestiller han sig 1824 troen som en hvælvet bro, »Der Iis-Gangen trodser i buldrende Strand, Fra DødningeHjem til de Levendes Land «. I 1872 er troen ikke nogen vidunder-bro, men en farefuld sejlads over et stort vildt hav, hvor det er let nok at strande på dødsrigets kyst, den nordiske mytologis Nastrond, eller at gå under og blive redningsløst fortabt, hvis ikke man har »Guds-Ordet« til »Kompas«. Kan

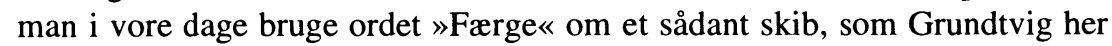
forestiller sig? - Ja, det har jeg selv set i Grønland, på Færgebilletten til sejladsen fra Holsteinsborg (Sisimiut) til Godhavn på øen Disko, hen over Davisstrædet, hvor stormene meget vel kan være frygtelige - men ikke var det, da jeg i 1980 var om bord.

Tonen er anderledes i de to sidste strofer, og derfor er strofeformen en anden og melodien ændret, nu i en rolig dur. 3. strofe er den centrale, den, hvori det afgørende siges: For os jordiske mennesker er drømmen om paradiset så fjern, at vi ikke kan se, hvordan vi skulle kunne nå derhen - og sådan er det også på dødens hav. Men paradiset er os dog nært overalt, »Hvor hos Ordet er Guds Priis«, dvs. når vi priser den overmenneskelige magt, $\mathrm{i}$ hvis hånd vi alle er prisgivne, og stoler på hans ord. Så åbner himmelhavnen sig lige så brat, som når tågen letter foran en grønlandsk havn. Og tiden bliver til evighed som i et eventyr. Det er derfor, Jesus er Kristus og foreningen af disse to navne skal prises evindelig.

Bag dette digt, uudtalt, ligger nemlig Jesu evangelium om syndernes forladelse. Som det ligger bag hele Grundtvigs liv, fra det øjeblik han fik brug for det i efteråret 1810. Og dermed blev kristen. Det skete ikke, uden at han blev bragt $\mathrm{i}$ den tvangssituation at skulle anmode kongen om at blive sin fars hjælpepræst. Men det skete. Og Grundtvig fortrød det aldrig. Paradiset åbnede sig først for ham, da han indså, at han havde brug for Jesu evangelium om syndernes forladelse. Det er ikke pietisme, men det $\mathrm{er}$ bodskristendom, en kristendom, som fører til glæde - »brat«, hvilket Noack siger er et yndlingsord for Kingo. Uden denne baggrund bliver glæden meningsløs, tom.

Derfor er det også nødvendigt at »bryde« med denne verden - som i Kingos »Far, Verden, Farvel« - hvilket er så svært, som det er sagt i Grundtvigs "At sige Verden ret Farvel « - før vi »indbydes til Guds-Bordet« i det evige liv. - Det er et digt, som Grundtvig kun kunne skrive, da han stod på falderebet og så døden som et stort, farefuldt hav, hvor kun troen på Jesu evangelium kunne føre ham til den rette havn, »Himmel-Havnen«. 